\title{
Reflex disturbances of cardiac rhythm during ophthalmic surgery
}

\author{
J. P. ALEXANDER \\ From Belfast City Hospital, Northern Ireland
}

The high incidence of cardiac arrhythmias during oral surgery under general anaesthesia has received considerable attention in recent years (Kaufman, 1966; Ryder, 1971). These arrhythmias have been attributed to reflex stimulation of the heart via the fifth cranial nerve together with the use of anaesthetic drugs such as halothane which sensitize the heart to the effects of endogenous or exogenous catecholamines. Although the reflex slowing of the heart after the ocular muscles have been stretched during strabismus surgery has been well documented (Sorenson and Gilmore, 1956; Kirsch, Samet, Kugel, and Axelrod, 1957; Reed and McCaughey, 1962; Apt, Isenberg, and Gaffney, 1973), other disturbances of cardiac rhythm during ophthalmic operations have received less attention. This investigation was undertaken to assess the frequency and severity of arrhythmias occurring during such operations.

\section{Method}

All patients undergoing operations on the eyeball under general anaesthesia administered by the author during a 4-year period have had cardiac rhythm continuously monitored with a cardiorater oscilloscope and intermittently recorded using a miniwriter recorder (Cardiac Recorders Ltd). Standard lead I I was employed. Monitoring began after induction of anaesthesia when the patient was brought into the operating theatre.

Altogether 219 patients will be considered, of whom 140 were children under the age of 14 undergoing strabismus surgery. The youngest was $2 \frac{1}{2}$ years old. The remaining 79 patients were aged 14 years and upwards and had a variety of ocular procedures under general anaesthesia. In addition, a further 15 patients who underwent cataract operations under local analgesia will also be considered.

\section{PREMEDICATION AND ANAESTHESIA}

Altogether 120 children had oral premedication with trimeprazine $(5 \mathrm{mg} / \mathrm{kg})$ or, in a few cases, diazepam

Address for reprints: Dr J. Alexander, 18 Cranmore Avenue, Belfast BT9 6JH.
$(0.2 \mathrm{mg} / \mathrm{kg})$. Twenty children were premedicated with intramuscular pethidine $(\mathrm{r} \cdot 3 \mathrm{mg} / \mathrm{kg})$ and atropine $(0.01 \mathrm{mg} / \mathrm{kg}$ ). Children under the age of 7 years had anaesthesia induced with nitrous oxide/oxygen/halothane, while the older children and adults received intravenous thiopentone or methohexitone followed by suxamethonium. All patients were intubated and anaesthesia was continued with nitrous oxide/oxygen and halothane 2 per cent initially and reduced as indicated clinically. Twenty children who had had oral premedication received atropine $0.01 \mathrm{mg} / \mathrm{kg}$ intravenously during the induction of anaesthesia. Two adult patients who underwent strabismus surgery also had intravenous atropine during induction. The remaining adults were premedicated with pethidine $1 \cdot 0-1 \cdot 5 \mathrm{mg} / \mathrm{kg}$ and atropine $0.6 \mathrm{mg}$ given intramuscularly one hour before surgery.

\section{Results}

\section{SQUINT OPERATIONS}

A total of 90 per cent of the patients who did not receive atropine demonstrated a positive oculo-cardiac reflex when traction was applied to the first eye muscle with a squint hook (usually the lateral rectus). Lesser degrees of deceleration were often observed during initial dissection of the conjuctiva. The mean change in 100 patients was a decrease of 30 beats/min (Table I). The maximum slowing observed was 100 beats $/ \mathrm{min}$, a drop from 150 to 50 beats $/ \mathrm{min}$, and the slowest heart rate recorded was 38 beats $/ \mathrm{min}$. In the patients who received intramuscular atropine, cardiac slowing occurred in 70 per cent, and in comparison with the patients who received no atropine, this did not demonstrate a statistically significant protective effect of intramuscular atropine against the oculo-cardiac reflex $\left(\chi^{2}=2.99\right.$; $P<0.1>0.05)$. In contrast, with intravenous atropine, there was cardiac slowing in 25 per cent of patients with a mean decrease in the rate of 2 beats $/ \mathrm{min}$, and this was highly significant when compared with the behaviour of patients who did not receive atropine at all $\left(\chi^{2}=40.0\right.$; $\mathbf{P}<0.001)$. Lesser decreases in heart rate were observed when the second muscle (usually the medial rectus) was stimulated.

Junctional rhythm (isorhythmic dissociation or 'nodal rhythm'), with disappearance, inversion, or shift of the $\mathbf{P}$ wave on the electrocardiogram as a response to eye 
Table I Heart rate changes in patients having squint operations, indicating use of atropine, dose and route administered, number of cases in each group, percentage showing oculo-cardiac (OC) reflex, mean heart rate changes (beats/min) in the group, (- equals minus), and standard deviations (SD) in parentheses

\begin{tabular}{|c|c|c|c|c|c|c|}
\hline \multirow[b]{2}{*}{ Atropine } & \multirow[b]{2}{*}{$\begin{array}{l}\text { Cases } \\
\text { (no.) }\end{array}$} & \multicolumn{2}{|c|}{ First muscle } & \multicolumn{2}{|c|}{ Second muscle } & \multirow[b]{2}{*}{$\begin{array}{l}\mathcal{F R} \\
\text { (per cent) }\end{array}$} \\
\hline & & $\begin{array}{l}\text { OC reflex } \\
\text { (per cent) }\end{array}$ & $\begin{array}{l}\text { Change in } \\
\text { heart rate } \\
\text { (beats/min) } \\
\pm S D\end{array}$ & $\begin{array}{l}\text { OC reflex } \\
\text { (per cent) }\end{array}$ & $\begin{array}{l}\text { Change in } \\
\text { heart rate } \\
\text { (beats } / \text { min) } \\
\pm S D\end{array}$ & \\
\hline $\begin{array}{c}\text { Children } \\
\text { none }\end{array}$ & 100 & 90 & $-30( \pm 25)$ & 72 & $-{ }_{5}( \pm 18)$ & 68 \\
\hline $\begin{array}{l}\text { intramuscular } \\
0.01 \mathrm{mg} / \mathrm{kg}\end{array}$ & 20 & 70 & $-17( \pm 16)$ & 55 & $-9( \pm 10)$ & 50 \\
\hline $\begin{array}{l}\text { intravenous } \\
0.01 \mathrm{mg} / \mathrm{kg}\end{array}$ & 20 & 25 & $-2( \pm 15)$ & $\circ$ & $+3( \pm 4)$ & 10 \\
\hline $\begin{array}{l}\text { Adults } \\
\text { intramuscular } \\
0.6 \mathrm{mg}\end{array}$ & 23 & 72 & $-17( \pm 15)$ & 25 & $-2( \pm 14)$ & 36 \\
\hline
\end{tabular}

Responses to first and second muscle stimulation are recorded. Last column shows percentage in each group who developed junctional rhythm (JR) as a response to ocular muscle stimulation

Statistical analysis Intramuscular atropine $v$. no atropine $\chi^{2}=2.99 ; \mathrm{P}<0.1>0.05$

Intravenous atropine $v$. no atropine $\chi^{2}=40.0 ; P<0.001$

muscle stimulation, was common although less so when atropine was used. While the maximum bradycardia produced by the oculo-cardiac reflex usually lasted from 20 to 60 seconds, junctional rhythm often persisted for several minutes. In ten children and two adults, heart rhythm was irregular during the period when slow junctional rhythm was present although the extrasystolic beats were of normal configuration (second beat, Fig. I, B). The mechanism of these arrhythmias appeared to be unique in that, at low heart rates, complexes originating in the junctional tissue could spread in a retrograde manner to activate the atria which then initiated a sinus beat (re-entry, Fig. I, B, at $\uparrow$ ).

Seven patients (five children and two adults) exhibited prolonged ectopic rhythms during squint surgery-the details are listed in Table II and they will be discussed in more detail later. These abnormal rhythms ceased at the termination either of surgery or of anaesthesia. Arterial blood samples taken while the abnormal rhythm was present were analysed for carbon dioxide tension which varied from 6.1 to $9.7 \mathrm{kPa}(46-73 \mathrm{mmHg})$ in four cases (average $7 \cdot 3 \mathrm{kPa}, 55 \mathrm{mmHg}$ ), although clinically anaesthesia was satisfactory and pulmonary ventilation appeared to be adequate.

\section{CATARACT OPERATIONS (GENERAL ANAESTHESIA)}

Electrocardiographic changes were common and occurred in 15 out of 25 patients. Junctional rhythm was seen in four cases, bradycardia in two, and occasional ectopic beats in ten (these were atrial in two, junctional in five, and ventricular in three). More than one arrhythmia could be seen in a patient and they were commoner in patients who were over 60 years of age. They could be related to the anaesthetic, to extraocular manipulations, to facial nerve block with local anaesthetic, and, in one case, to manipulation of the iris. Persistent bidirectional junctional ectopic arrhythmias were observed in two patients.

\section{IRIDECTOMY (GENERAL ANAESTHESIA)}

Eight of 24 patients developed ectopic beats of varying frequency and origins, and a further five had a positive oculo-cardiac reflex in response to traction on ocular muscles or on the iris.

\section{ENUCLEATION (GENERAL ANAESTHESIA)}

There were five patients and electrocardiographic changes were observed in four-namely, sinus tachycardia, frequent ectopic beats, bidirectional junctional tachycardia (Fig. 2, G), and bradycardia-during traction on ocular muscles in an apparently fit 74-yearold man. This patient died suddenly on the third postoperative day; the cause of death was not established.

\section{CATARACT OPERATIONS (LOCAL ANALGESIA)}

All 15 patients were over 60 years of age. Thirteen had increases in heart rate related to the retrobulbar and facial nerve blocks performed with 8-10 $\mathrm{ml}$ of 2 per cent lignocaine with $I$ in 100000 adrenaline and hyaluronidase. Occasional ectopic beats were common, being atrial in five, ventricular in four, and junctional with aberration in one apprehensive patient. Once the local 

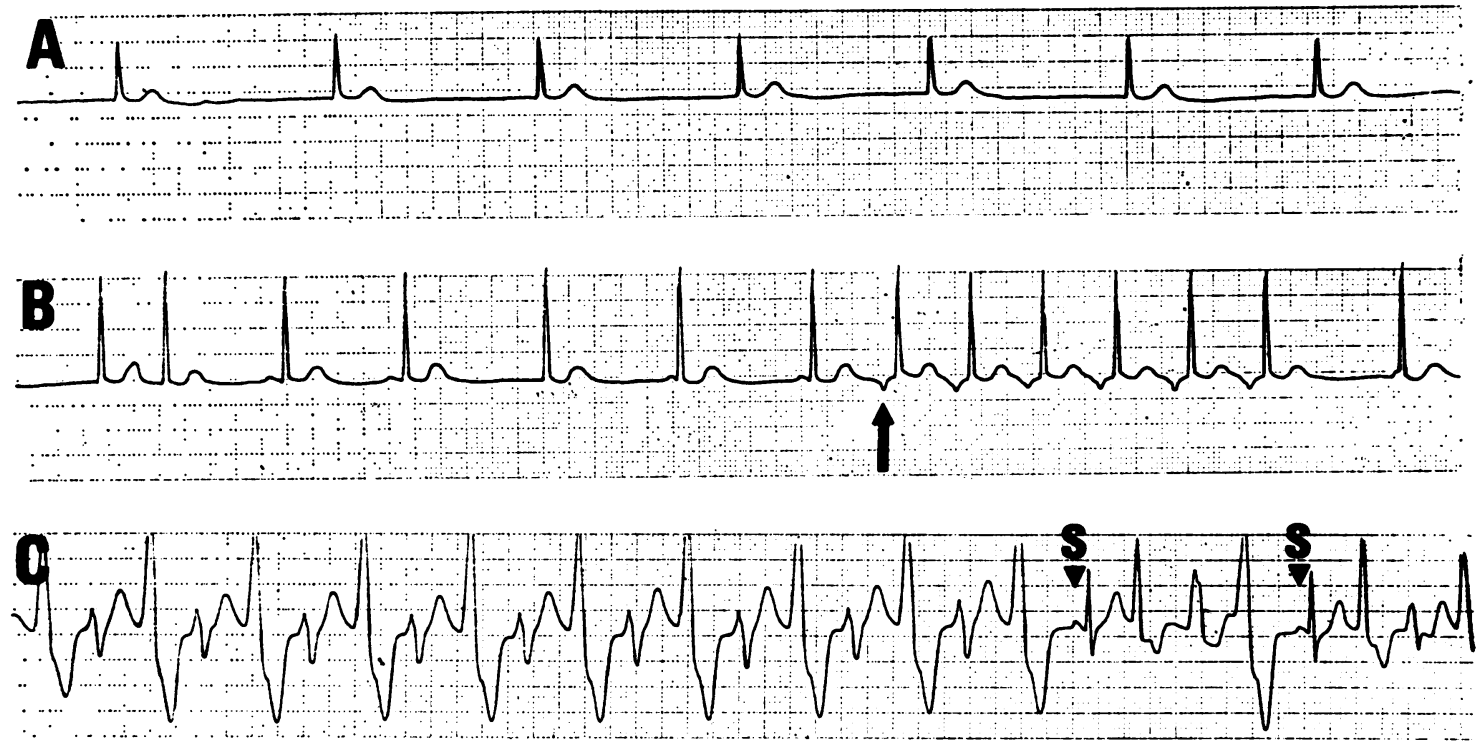

FIG. I

A functional bradycardia (rate $38 / \mathrm{min}$ ) in a boy aged 8 during medial rectus traction

B functional rhythm (6o/min) in a girl aged $\mathrm{I} 2$ on lateral rectus traction. $\uparrow$ marks the start of a short period of re-entry tachycardia

C Bidirectional junctional tachycardia (rate $150 / m i n)$ during squint surgery on a boy aged 1 . At $\mathbf{s}$ the cycle lengthens from 480 msec to $600 \mathrm{msec}$ allowing supernormal conduction of sinus beats

Paper speed $25 \mathrm{~mm} / \mathrm{s}$

block had taken effect, cardiac rhythm was generally stable and there were no changes in rate or rhythm associated with extra- or intraocular manoeuvres.

\section{Discussion}

The oculo-cardiac reflex was first described nearly 70 years ago (Aschner, 1908; Dagnini, 1908) and has also been referred to as the trigemino-vagal reflex (Kirsch and others, 1957). Using animal preparations, Aschner found that an intact trigeminal nerve was required to produce the reflex slowing of the heart, an effect more readily evoked in the anaesthetized animal. Afferent nerve fibres run through the short and long ciliary nerves and the efferent path from the brain is the vagus. The importance attached to this reflex is attested to by the impressive number of papers which have been published on the subject (Sorenson and Gilmore, 1956; Walton, 1957; Kirsch and others, 1957; Bosomworth, Ziegler, and Jacoby, 1958; Reed and McCaughey, 1962). Cardiac arrest as a response to the reflex has been reported by Walton (I957), Sorenson and Gilmore (1956), Mallinson and Coombes (1960), Kirsch and others (1957), and Smith, Douglas, and Petruscak (1972).

The data presented here support the observations made by Sorenson and Gilmore (1956) and Rhode,
Grom, Bajares, Anselmi, Capriles, and Rivas (1958) that about 90 per cent of children will show the reflex if atropine is not used, and those of Walton (1957), Bosomworth and others (1958), and Reed and McCaughey (1962) that intravenous atropine has a reliably protective action. Sorenson and Gilmore (1956) and Mendelblatt, Kirsch, and Lemberg (1962) thought that traction on the medial rectus muscle caused more profound slowing of the heart; however, in this series the lateral rectus muscle was usually operated on first and manipulation of it caused the more profound bradycardia. A smaller response to the second muscle is presumably due to the effect of fatigue on the reflex (evident in Table I); this was pointed out by Platen (1958) and Moonie, Rees, and Elton (1964).

It was noted that mean cardiac slowing was 49 beats/min in the first 20 , and only 16 beats/min in the last 20 non-atropinized patients in the series, which suggested that the surgeon was being more gentle when he realized the effect he could produce. Using an unpaired t-test, these figures showed a significant difference $(t=2.38 ; P=0.05)$. No attempt was made at any time to produce an exaggerated reflex by forcible traction on the ocular muscles.

Sustained ectopic arrhythmias have not previously 
Table II Classification of sustained arrhythmias observed during monitoring of 219 patients undergoing ocular surgery (incidence 4.6 per cent)

\begin{tabular}{|c|c|c|c|}
\hline Operation & $\operatorname{Sex}$ & $\begin{array}{l}\text { Age } \\
\text { (yrs) }\end{array}$ & Arrhythmia \\
\hline Squint & $\mathbf{F}$ & 9 & $\begin{array}{l}\text { Bidirectional tachy- } \\
\text { cardia (rate } 180 / \mathrm{min} \text { ) }\end{array}$ \\
\hline Squint & $\mathbf{F}$ & 12 & $\begin{array}{l}\text { Bigeminal ectopics } \\
\text { with aberration }\end{array}$ \\
\hline Squint & $\mathbf{M}$ & I I & $\begin{array}{l}\text { Bidirectional tachy- } \\
\text { cardia (rate } 150 / \mathrm{min} \text { ) }\end{array}$ \\
\hline Squint & $\mathbf{M}$ & 7 & $\begin{array}{l}\text { Bigeminal ectopics } \\
\text { (rate } 140 / \mathrm{min} \text { ) }\end{array}$ \\
\hline Squint & $\mathbf{M}$ & 7 & $\begin{array}{l}\text { Junctional bigeminy, } \\
\text { bidirectional, varying } \\
\text { aberration }\end{array}$ \\
\hline Squint & $\mathbf{F}$ & 46 & $\begin{array}{l}\text { Bidirectional junctional } \\
\text { ectopics before } \\
\text { surgery, bidirectional } \\
\text { tachycardia during } \\
\text { surgery }\end{array}$ \\
\hline Squint & $\mathbf{F}$ & $5^{8}$ & $\begin{array}{l}\text { Bidirectional tachy- } \\
\text { cardia (rate } 150 / \mathrm{min} \text { ) } \\
\text { changing to } \\
\text { junctional rhythm } \\
\text { (rate } 90 / \mathrm{min} \text { ) with } \\
\text { superior rectus } \\
\text { traction }\end{array}$ \\
\hline Enucleation & $\mathbf{F}$ & 55 & $\begin{array}{l}\text { Bidirectional tachy- } \\
\text { cardia (120/min) } \\
\text { with aberration }\end{array}$ \\
\hline Cataract & $\mathbf{M}$ & 67 & Bidirectional bigeminy \\
\hline Cataract & $\mathbf{F}$ & 59 & Bidirectional ectopics \\
\hline
\end{tabular}

been a feature of reports describing the effects of ophthalmic operations on cardiac rhythm, although isolated ectopics and bigeminal rhythms have been described both in humans (Sorenson and Gilmore, 1956) and, as a result of ocular stimulation, in animal experiments (Rhode and others, 1958). The latter considered that hypoxia in their animals was an important contributing factor, but hypoxia has not been obvious in clinical practice in humans. Schamroth (1958) showed that eyeball compression frequently led to ectopic cardiac rhythms in nonanaesthetized humans, particularly if they suffered from heart disease. Similar arrhythmias have been observed in patients undergoing oral surgery under light halothane anaesthesia, and have been shown to be due to disturbances of the junctional tissues of the heart. The term junctional is preferred to nodal since the atrioventricular nodal region has been described to include three anatomically and physiologically distinct areas (Hecht, Kossmann, Childers, Langendorf, Lev, Rosen, Pruitt, Truex, Uhley, and Watt, 1973; De Carvalho and Almeida,
I960). The arrhythmias can be divided into three groups for descriptive purposes.

\section{Functional rhythm or isorhythmic dissociation}

This is a common disturbance of rhythm in which there are two sites of automaticity in the conducting tissue of the heart, one proximal and one distal to the atrioventricular node, which are firing at almost the same rate. The $P$ wave of the electrocardiogram may be obscured by the QRS complex as in Fig. I, $A$, or the atria may be activated in a retrograde manner in which case the $P$ waves are inverted (Fig. I, B).

\section{Functional ectopic beats}

These occurred frequently and confirmed the increased automaticity of the atrioventricular junctional tissues during surgical stimulation under halothane anaesthesia (Alexander, Bekheit, and Fletcher, 1972). The ectopic pacemaker is located above the His bundle and conduction through depressed fibres (due to the anaesthetic drugs or to autonomic control) shows increased sensitivity to changes in rate which may result in variable degrees of delay and block, which are then expressed as aberrant conduction (Fig. 2, D). In the normal ventricular conduction system, increases in rate do not cause conduction delay or block (Cranefield, Wit, and Hoffman, 1973).

\section{Bidirectional junctional tachycardia}

At a critical ventricular rate, there is alternate delay in conduction down one or other Purkinje system, so that the complexes show alternate right and left bundle branch block in lead I I (Fig. I, C; Fig. 2, E, F, G). This explains their bidirectional appearance and is a physiological reason depending upon the relationship of the refractory period of the His bundles to a critical heart rate, and is not necessarily due to organic obstruction of conduction. However, bidirectional tachycardia has usually been regarded as a serious disturbance of rhythm, and has been described in digitalis toxicity and in acute myocardial infarction (Roesler and Fletcher, 1963).

These disturbances of cardiac rhythm were common in patients having oral surgery under light halothane anaesthesia (Alexander, 1971), and here it was thought that the response to tooth extraction led to reflex stimulation of the cardiac sympathetic nerves. Ryder and Townsend (1974), in a recent review of various techniques for dental anaesthesia, concluded that, although arrhythmias were most common with halothane, it was the only agent capable of providing, consistently, anaesthesia of 

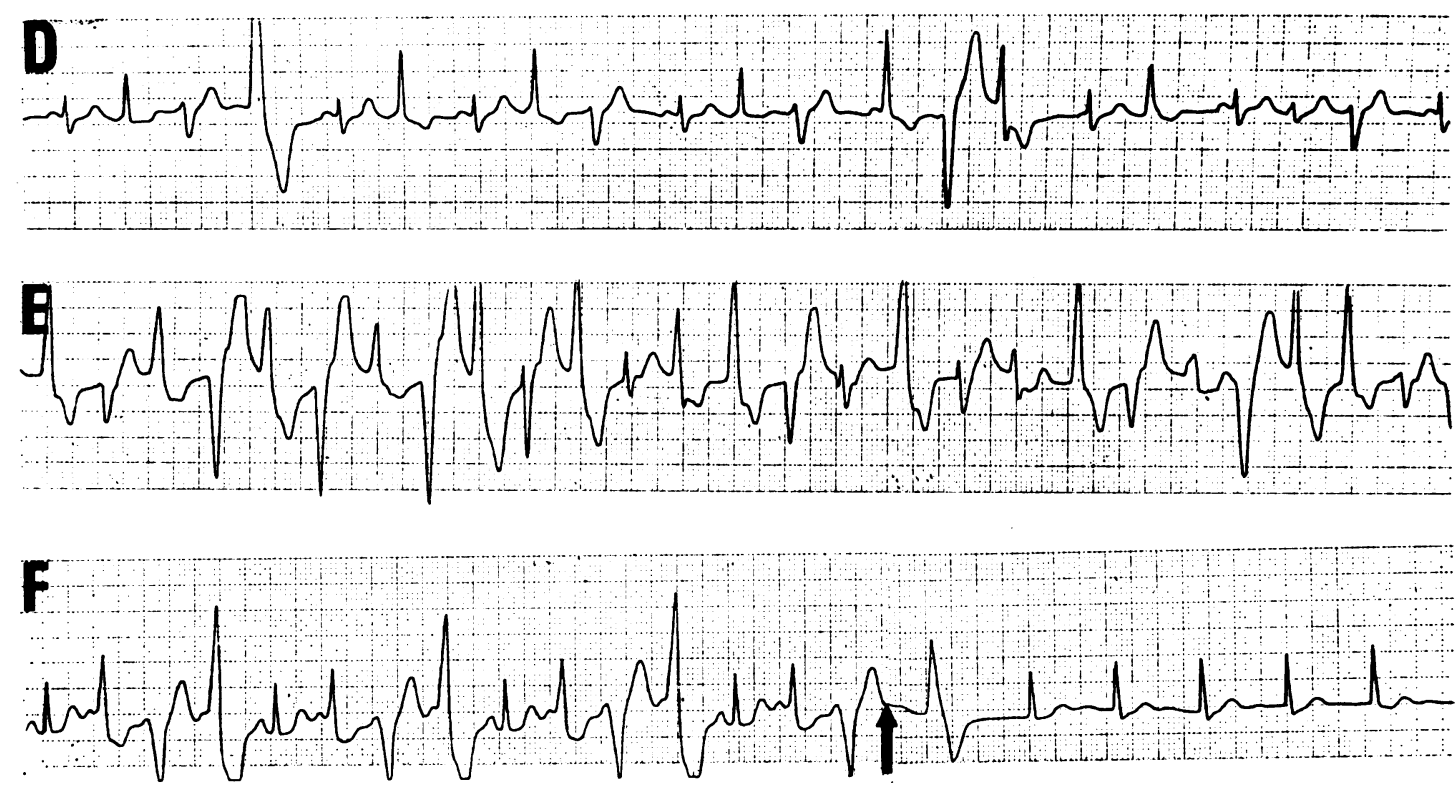

G

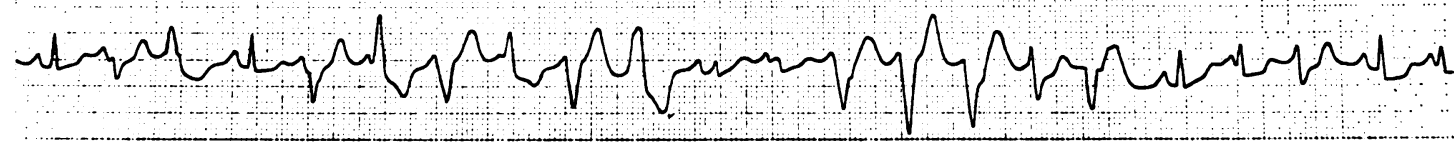

FIG 2

D Bidirectional ectopic complexes after induction of anaesthesia and before surgery in a 46-year-old woman. Atropine $0.3 \mathrm{mg}$ given intravenously during induction

E Same patient as $D$. After traction on the medial rectus, a period of bidirectional tachycardia develops

F Frequent bidirectional ectopics (rate $120 / \mathrm{min}$ ) after induction of anaesthesia in a 58-year-old woman. The rhythm changes to junctional (rate $90 / \mathrm{min}$ ) with superior rectus muscle traction. There is a break in the record at $\uparrow$

G $A$ short period of bidirectional tachycardia during enucleation in a 55-year-old woman. There is varying aberration of ectopic complexes

$D, F$, and $G$ start with a normal sinus beat

acceptable quality. In the author's experience, the mild respiratory acidosis associated with the use of the drug, which was confirmed in a few cases in this study, rarely leads to arrhythmia in the absence of surgical stimulation, although Johnstone (I950) showed that very high carbon dioxide tensions frequently produced arrhythmias of various types.

Although intravenous atropine in adequate doses gives almost complete protection against the oculocardiac reflex, this is at the expense of high heart rates (frequently $150-180$ beats/min in small children). This parasympatholytic action may not always be benign. Eger (1962) considered that the injection of atropine intravenously in the presence of cyclopropane or halothane anaesthesia may produce disastrous arrhythmias. Case 6 (Table II) developed an ectopic rhythm after induction (which included intravenous atropine) which became grossly abnormal after surgical stimulation (Fig. 2, $\mathrm{D}$ and $\mathrm{E}$ ). The delicate balance between sympathetic and parasympathetic control of the heart is illustrated by Case 7 who developed a bidirectional tachycardia after induction (rate $150 / \mathrm{min}$ and pulse regular) which slowed to 90 beats/min with junctional rhythm when traction was applied to the superior rectus muscle (Fig. 2, F).

\section{RETROBULBAR BLOCK}

According to Taylor, Wilson, Roesch, and Stoelting (1963), Mallinson and Coombes (1960), Kirsch and others (1957), and Mendelblatt and others (1962), retrobulbar block gives good protection against the 
oculo-cardiac reflex. On the other hand, Bosomworth and others (1958) and Reed and McCaughey (r962) did not consider it to be so effective. Smith and others (1972) recently reported two cases of sinus arrest during surgery on adult patients who had received general anaesthesia and retrobulbar block. We are not in a position to assess the effectiveness of blocks done under anaesthesia, but in the I 5 cataract operations performed under retrobulbar and facial nerve block which were monitored, heart rhythm and rate were stable once the block had taken effect, occasional ectopics or heart rate changes before this seemingly being due to the stimulus of needle prick or to the adrenaline in the solution.

Gartner and Billet (1958) estimated that about 45 deaths occurred annually during eye surgery in the USA, and that most of these were in patients under the age of 7 years. Sorenson and Gilmore (1956) suggested two mechanisms leading to cardiac arrest -either bradycardia leading to sinus arrest, or more rarely extrasystoles and ventricular fibrillation, both responses occurring when the ocular muscles were being mobilized. Landman and Ehrenfeld (1952) described ventricular fibrillation resulting from eyeball pressure used in an attempt to abolish an established arrhythmia.

It has already been mentioned that bidirectional tachycardias are not common except in patients suffering from severe disease. Such arrhythmias are considered by some cardiologists to be benign if the heart is healthy, although the effects of hypoxia or hypercarbia which may occur during anaesthesia are unknown (Deacock and Oxer, 1962). Such arrhythmias may be unsuspected if reliance is placed solely on monitoring the pulse, which may feel rapid and regular, or regular at half the ventricular rate. They can be reliably detected only by electrocardioscopic monitoring. They almost invariably respond to beta adrenergic blocking agents such as practolol (Rollason and Hall, 1973), or more simply, to a reduction in the surgical stimulation.

\section{Summary}

Cardiac rhythm was monitored in 219 patients who had ocular operations under general anaesthesia and in 15 patients who had cataract surgery under local analgesia. Of these, 140 were children having squint surgery. The high incidence of the oculo-cardiac reflex and the adequate protective effect of atropine $0.01 \mathrm{mg} / \mathrm{kg}$ given intravenously was confirmed. Isolated extrasystoles were common, particularly in older patients, and sustained ectopic cardiac arrhythmias were observed in 4.6 per cent of patients of all ages. The significance of these arrhythmias in relation to surgical stimulation and the anaesthetic drugs used is discussed.

I am grateful to Dr P. Morton, Dr G. Murtagh, and in particular Dr S. Bekheit of the Cardiological Investigation Department of the Belfast City Hospital for their help in interpreting the electrocardiograms, and to $\mathrm{Mr}$ P. J. Gormley, FRCS, for his interest in this investigation and for access to his patients.

\section{References}

alexander, J. P. (1971) Brit. F. Anaesth., 43, 773

-, BEKHEIT, S., and FLETCHER, E. (1972) Ibid., 44, I 179

APT, L., ISENBERg, s., and GAFFNey, w. L. (1973) Amer. F. Ophthal., 76, 533

ASCHNER, B. (1908) Wien. med. Wschr., 21, 1529

BOSOMWORTh, P. P., ZIEGLER, C. H., and JACOBY, J. (1958) Anesthesiology, 19, 7

CRANEFIELD, P. F., WIT, A. L., and hOFFMAN, B. F. (1973) Circulation, 67, 190

DAGNINI, G. (1908) Bull. Sci. med. Bologna, 8, 380

DEACOCK, A. R. de C., and OXER, H. F. (1962) Brit. F. Anaesth., 34, 45 I

DE CARValho, A., and Almeida, D. F. (1960) Circulat. Res., 8, 801

EGER, E. I. (1962) Anesthesiology, 23, 365

GARTNER, s., and BILLET, E. (1958) Amer. F. Ophthal., 45, 847

HEChT, H. H., KOSSMANN, C. E., CHILDERS, R. W., LANGENDORF, R., LEV, M., ROSEN, K. M., PRUITT, R. D., TRUEX, R. C.,

Uhley, H. N., and WaTt, T. B. (1973) Amer. F. Cardiol., 31, 232

JOHNSTONE, M. (1950) Brit. Heart f., 12, 239

KaUfMan, L. (1966) Proc. roy. Soc. Med., 59, 731

KIRSCH, R. E., SAMET, P., KUGEL, V., and AXELROD, S. (1 957) Arch. Ophthal., 58, 348

LANDMAN, M. E., and EHRENFELd, I. (1952) Amer. Heart $\mathcal{F}$., 43, 791

MALliNSON, F. B., and COOMBES, S. K. (1960) Lancet, I, 574

MENDELblatT, F. I., KIRSCH, R. E., and LEMBERG, L. (I962) Amer. F. Ophthal., 53, 506

MOONIE, G. T., REES, D. L., and elton, D. (1964) Canad. Anaesth. Soc. F., I1, 621

Platen, J. TH. (1958) Ophthalmologica (Basel), r35, 287 
REED, H., and MCCAUGHEY, T. (1962) Brit. F. Ophthal., 46, I 12

RHODE, J., GROM, E., BAJARES, A. C., ANSELMi, A., CAPRILES, M. A., and RIVAS, c. (1958) Amer. F. Ophthal., 46, 367 ROESLER, H., and FLETCHER, E. (1963) 'An Atlas of Electrocardiology', p. 609. Wright, Bristol Rollason, W. N., and HALl, D. J. (1973) Anaesthesia, 28, 139 RYDER, w. (1971) Proc. roy. Soc. Med., 64, 82 , and TOWNSEND, D. (1974) Brit. F. Anaesth., 46, 760 sChamroth, L. (1958) Amer. $\mathcal{F}$. Cardiol., 2, 321 SMith, R. B., Douglas, H., and PETRusCak, J. (1972) Canad. Anaesth. Soc. F., 19, 138 SORENSON, E. J., and GILMORE, J. E. (1956) Amer. F. Ophthal., 41, 748

TAYLOR, C., Wilson, F. M., ROESCh, R., and stoklting, v. K. (1963) Anesthesiology, 24, 646 walton, F. A. (1957) Canad. Anaesth. Soc. F., 4, 414 